\title{
Effect of Naturally Collected Bacteria on Growth of Uroglena americana, a Freshwater Red Tide Chrysophyceae
}

\author{
Bon Kimura, ${ }^{* 1,2}$ Yuzaburo Ishida, ${ }^{* 1}$ and Hajime Kadota ${ }^{* 1,3}$ \\ (Accepted August 23, 1985)
}

\begin{abstract}
It was demonstrated that the presence of bacteria was essential for the growth of $U$. americana, a freshwater red tide Chrysophyceae, in a laboratory culture system. The effect on the algal growth of bacteria collected from Lake Biwa during the bloom was studied. All of the bacteria tested supported the algal growth; and the growth extent of the alga was dependent on the species of associated bacteria. The algal growth was also promoted with the addition of nonsterilized natural lake water. The possible role of bacteria for the algal growth in nature was discussed.
\end{abstract}

In order to elucidate a mechanism of outbrake of a freshwater red tide of $U$. americana in Lake Biwa, Ishida et al. ${ }^{1)}$ conducted an algal assay for analysis of major nutrients limiting the algal growth in the lake. However, the culture of $U$. americana used in this study was not an axenic, but a monoxenic one which was accompanied by a strain of bacteria. The alga, first isolated in 1978 from Lake Biwa during its bloom, was successfully grown in a bacterized unialgal culture using chemically defined medium (Ur-1), but failed to grow in bacteria-free condition.

The present paper describes that the algal growth is dependent on the presence of an associated bacteria, and that all of bacterial strains collected from Lake Biwa during the algal bloom are effective on the algal growth.

\section{Materials and Methods}

\section{Isolation and Cultivation of $\mathrm{U}$. americana}

$U$. americana strain 78 was isolated in 1978 from Lake Biwa. The monoxenic culture of $U$. americana, which was accompanied by a bacterial strain NA-1 (Vibrio-Aeromonas sp.), was obtained by washing the algal colonies 10 to 15 times in petri-dishes containing $0.5 \mathrm{~m} l$ of sterilized $\mathrm{Ur}-1$ medium $^{12}$ with the help of capillary pipettes. Stock cultures of $U$. americana were maintained in sterile paper-plugged (New Steri-Plug; W. Germany) $100-\mathrm{m} /$ Erlenmeyer flasks containing
$40 \mathrm{~m} /$ of chemically defined medium Ur-1, and transferred at intervals of 2 weeks. The composition of Ur-1 medium is as follows (per l): $\mathrm{NH}_{4} \mathrm{NO}_{3}$, $5 \mathrm{mg} ; \mathrm{NaH}_{2} \mathrm{PO}_{4}, 1.7 \mathrm{mg} ; \mathrm{MgSO}_{4}, 10 \mathrm{mg} ; \mathrm{CaCl}_{2}, 10$ $\mathrm{mg}$; $\mathrm{KCl}, 1 \mathrm{mg}$; vitamin $\mathbf{B}_{1}, 10 \mu \mathrm{g}$; vitamin $\mathbf{B}_{\llcorner 2}$, $0.1 \mu \mathrm{g}$; biotin, $0.1 \mu \mathrm{g}$; Provasoli's PIV metal solution, ${ }^{2} 1 \mathrm{~m} / ; \mathrm{pH} 7.0$.

Growth Conditions and Measurements of $\mathrm{U}$. americana

For all growth experiments, $0.1 \mathrm{~m} /$ of the subcultures incubated for one week was inoculated into tripricate sterile Pyrex test-tubes plugged with P.P caps containing $4 \mathrm{~m} /$ of Ur 1 medium. Conditions for incubation were as follows: $15^{\circ} \mathrm{C}$ and $6000 \mathrm{~lx}$ cool white or daylight fluorescent on a 14-h light/10-h dark cycle. The growth of the cultures was monitored by measuring in vivo chlorophyll fiuorescence of a $4 \mathrm{~m} l$ sample tube. Measurements were made with a Turner Model 111 Fluorometer, modified for chlorophyll analysis.

Experimental Procedure for Bacterial Effect on the Growth of U. americana

(1) Preparation of a temporary axenic culture of $U$. americana

To make $U$. americana culture axenic, $1.5 \mu \mathrm{g} / \mathrm{m} l$ of filter-sterilized erythromycin was added to Ur-1 medium. A bacterial strain NA-1 associated with $U$. americana did not grow in the presense of more than $0.19 \mu \mathrm{g}$ (per $\mathrm{ml}$ ) of erythromycin.

*1 Laboratory of Microbiology, Department of Fisheries, Faculty of Agriculture, Kyoto University, Kyoto 606, Japan (木村 凡, 石田裙三郎, 門田 元: 京都大学费学部水座微生物研究室).

*2 Present address: Laboratory of Microbiology, Department of Food Science and Technology, Shimono-

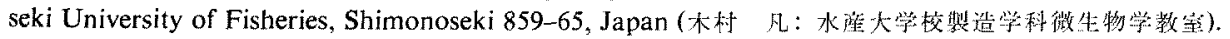

*3 Present address： Department of Fisheries, Kinki University, Higashi-Osaka 577, Japan (門时 元：近幾 大学盏学部水座学科). 
After inoculating the alga, viability of a bacterial strain NA-1 was examined by use of $\mathrm{LT}_{10}^{-1}$ medium $^{3)}$ containing $0.5 \mathrm{~g}$ of trypticase peptone (BBL), $0.05 \mathrm{~g}$ of yeast extract (Difco), and $1 /$ of aged lake water.

(2) Stability test of the antibiotic in the algal culture

Stability of the antibiotic (erythromycin) in the culture was assayed by the agar diffusion method. Bacillus subtillus (erythromycin-sensitive) as a test organism was spread on agar plates and metal cups containing samples were placed on the surface. After $24 \mathrm{~h}$ of incubation at $30^{\circ} \mathrm{C}$, the clear zones on the plates were measured.

(3) A culture system for a bacterial effect on the growth of $U$. americana.

To examine bacterial effects on the algal growth, one hundred seventy-seven bacterial strains were isolated from Lake Biwa during April 16 to June 18,1981 , and among them 68 erythromycin-resistant strains were selected for an experiment employing a temporary axenic culture treated with erythromycin.

However, there is a limitation that erythromycinsensitive bacteria could not be tested in this system. We, therefore, prepared a new monoxenic culture system, in which the bacterial strain NA-1 associated with $U$. americana in the stock culture was replaced by an extremely slower growing bacterium strain 2B-11. To this culture system, each 24 strains of bacteria isolated from Lake Biwa on Apr. 27, May 9, 13 and 25, and Jun. 23 (1983) were inoculated and the algal growth was assayed after 14 days of incubation.

(4) The effects of sterilized and nonsterilized lake waters on the growth of $U$. americana.

Lake water samples were collected from Lake Biwa during the period of initial phase (Apr. 27, 1983) to final phase (Jun. 23, 1983) of the algal bloom. The samples were filtered through a combusted glass fiber filter immediately after sampling water. A portion of filtrates was sterilized by autoclaving at $121^{\circ} \mathrm{C}$ for $15 \mathrm{~min}$. For the growth response test, $0.1 \mathrm{ml}$ of either samples was added to the test tubes containing $4 \mathrm{~m} /$ of Ur-1 medium. The cultures were incubated for 14 days at light.

(5) In situ populations of U. americana and bacteria.

Population density of $U$. americana in situ was determined by counting its colony number in $0.5 \mathrm{ml}$ of each water samples using hemacytometers immediately after sampling waters.

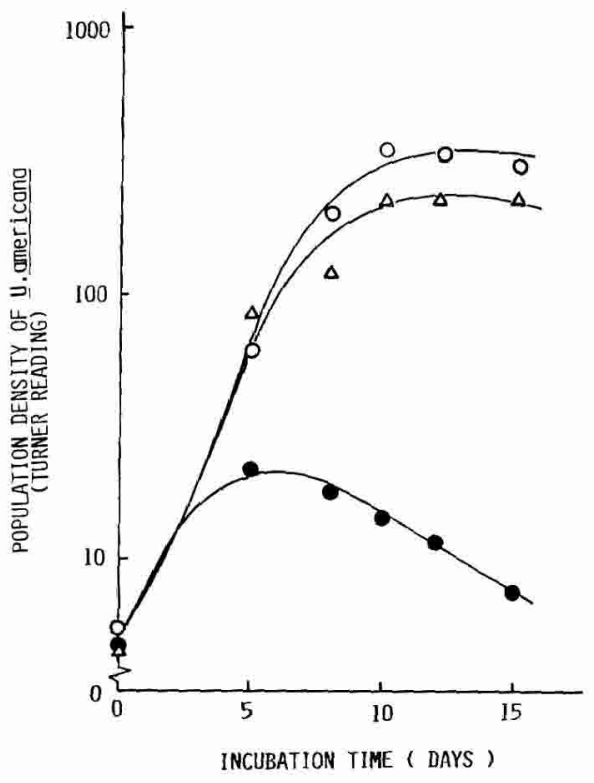

Fig. 1. Growth of $U$. americana in the presence and absence of associated bacteria. $U$. americana culture accompanied by an erythromycinsensitive bacterium NA-1 (O) was added with $1.5 \mu \mathrm{g} / \mathrm{ml}$ of erythromycin ( ) or erythromycin plus erythromycin-resistant bacterium $\mathrm{NbA}-1$ $(\Delta)$.

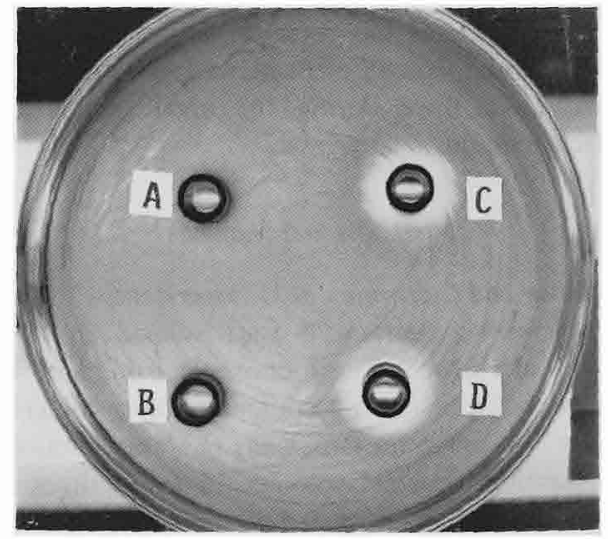

Fig. 2. Stability of erythromycin added to $U$. americana culture after 12 days of incubation. Bacillus subtillis as a test organism was spread on an agar plate, and metal cups placed in the agar were filled with the algal cultures which had been incubated for 12 days with no addition (A), with an erythromycin-resistant bacterium $\mathrm{NbA}-1$ (B), with $1.5 \mu \mathrm{g} / \mathrm{ml}$ of erythromycin (C), and with $1.5 \mu \mathrm{g} / \mathrm{ml}$ of erythromycin plus the bacterium NbA-1 (D). Note the same inhibition zone size in (D) as in (C). 
The number of bacteria in samples was counted by the spread plate method with LT $10^{-1}$ medium after three weeks of incubation at $20^{\circ} \mathrm{C}$.

\section{Result}

Growth Response of U. americana to Bacteria in the Presence of Erythromycin

Chemically defined medium Ur-1 supported good growth of the monoxenic culture of $U$. americana which was accompanied by an eryerythromycin-sensitive bacterial strain NA-1 (Vibrio-Aeromonas sp.) (Fig. 1). However, after being made axenic by erythromycin. the alga failed to grow (Fig. 1). The growth in the erythromycin-added culture was recovered when inoculated with an erythromycin-resistant bacterial strain NbA-1 (Fig. 1). The erythromycinstability test employing the agar diffusion method demonstrated that erythromycin was not decomposed by the bacteria in this culture during the course of the experiments (Fig. 2). These results present evidence that the presence of bacteria is an essential factor for the growth of $U$. americana.

Sixty-six strains among 68 erythromycin-resistant bacteria isolated from Lake Biwa in 1981 supported the growth of $U$. americana when examined in a similar system with that shown in Fig. 1, and the extent of the algal growth was variable, depending on the species of associated bacteria. Fig. 3A shows two typical examples. The growth of $U$. americana in a mixed culture with bacterial strain 3A-3 showed distinct increase over 7-10 days, whereas the alga in a mixed culture with bacterial strain 2B-11 increased very slowly over a period of 40 days and subsequently reached only $40-60 \%$ of the yield of the cultures accompanied by bacterial strain 3A-3. During
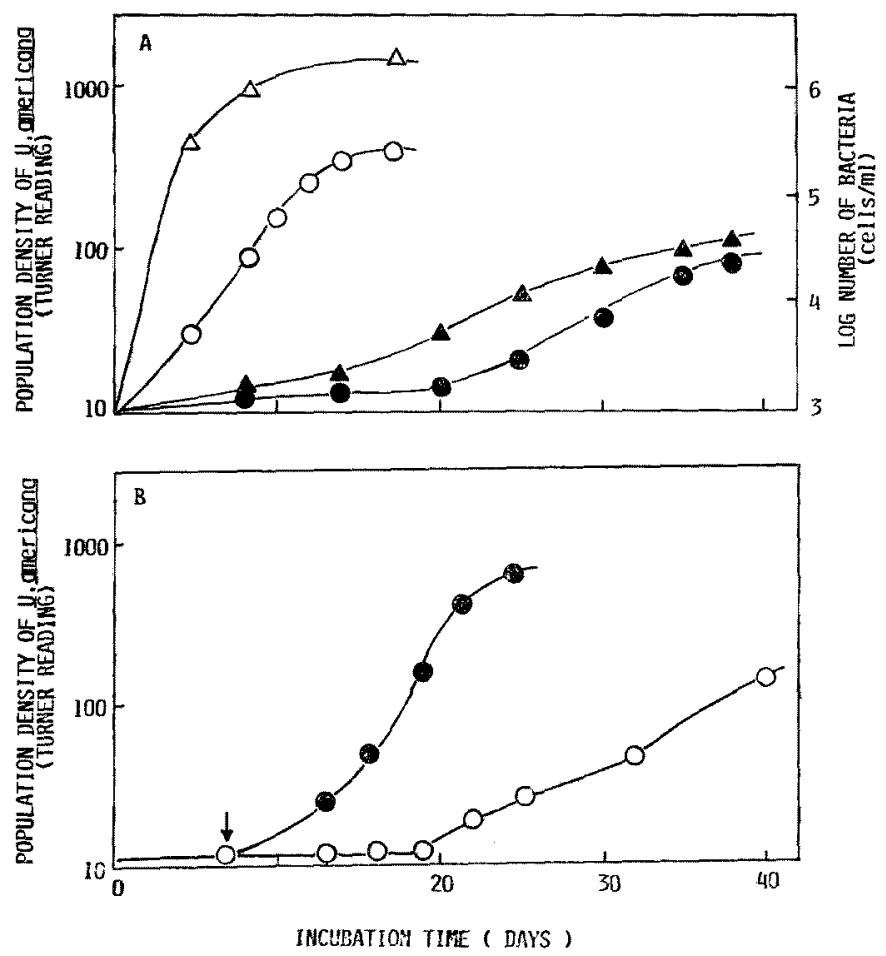

Fig. 3. (A) Growth of $U$. americana and two erythromycin-resistant bacteria in mixed cultures. Conditions for inoculum and incubation were same as described in the legend to Fig. 1. Symbols: $O, U$. americana with a rapid growing bacterium $3 \mathrm{~A}-3 ; \Delta$, the bacterium $3 \mathrm{~A}-3$ with with $U$. americana; $\bullet, U$. americana with a slow growing bacterium $2 \mathrm{~B}-11 ; \mathbf{A}$, the bacterium 2B-11 with $U$. americana. (B) Effect of the supplemental inoculation of a bacterium 3A-3 on the growth of $U$. americana accompanied by the bacterium $2 \mathrm{~B}-11$. Arrow indicates the addition of the bacterium 3A-3. Symbols: $O$, $U$. americana with the bacterium 2B-11; $U$. americana with the bacterium $2 \mathrm{~B}-11$ and $3 \mathrm{~A}-3$. 


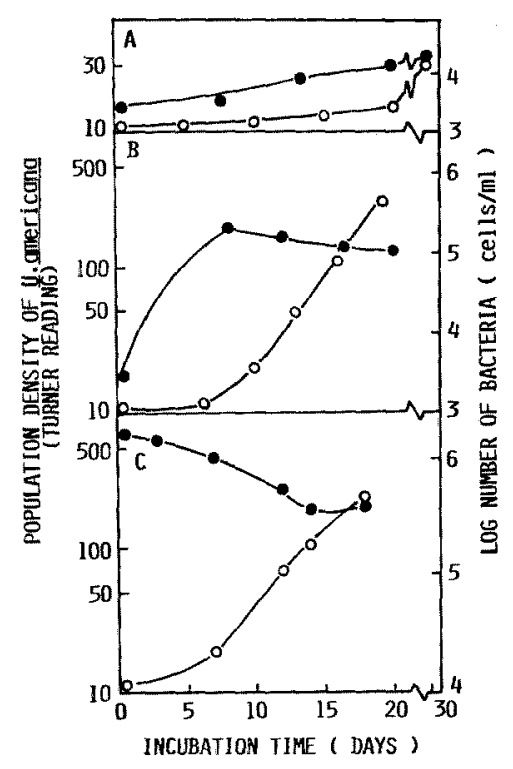

Fig. 4. Growth of $U$. americana $(O)$ and bacterium 2B-11 (-) in the mixed culture system in Ur-1 medium. (A) no addition. (B) with $50 \mathrm{mg} / \mathrm{l}$ tryticase peptone. (C) with additional supplement of a washed suspension of the bacterium (the initial number of the bacterium $10^{\circ} / \mathrm{ml}$ ).

the course of the experiments the number of bacterial strain 2B-11 remained remarkably low as compared with that of a bacterial strain $3 \mathrm{~A}-3$ (Fig. 3A). Subsequent transfer of these cultures yielded virtually identical results. The growth of $U$. americana accompanied by bacterium $2 \mathrm{~B}-11$ was enhanced by additionally inoculating a bacterium $3 \mathrm{~A}-3$ to the culture (Fig. 3B). The growth of $U$. americana accompanied by a bacterium $2 \mathrm{~B}$ 11 was also made much more enhanced by adding a small amount of peptone to promote the bacterial growth (Fig. 4B) or by making the initial number of bacteria higher (ca. $10^{6}$ per $\mathrm{ml}$ ) (Fig. 4C).

The Effect on the Algal Growth of Various Bacterial Strains Isolated from Lake Biwa during the Bloom (1983)

To examine the effects of various bacterial strains on the algal growth, it is disadvantageous to employ the temporary axenic culture with erythromycin as an assay system, because erythromycin-sensitive bacteria can not be tested in this system. One hundred twenty strains of bacteria isolated from Lake Biwa during the period of initial phase to final phase of the bloom of $U$. americana (1983) were therefore inoculated each to the algal culture accompanied by a slow growing bacterium 2B-11 without erythromycin and the algal growth was assayed. Results were summerized in Table 1. All of the bacteria except one enhanced the growth of $U$. americana. In preliminary experiments several bacteria inhibited the algal growth. These inhibitory effects appeared mostly due to excessive growth of bacteria, but by making inoculum size lower, most of these inhibitory effects disappeared.

\section{In Situ Relationships between U. americana and} Bacteria

Fig. 5 shows the population density of $U$. americana and bacteria during the algal bloom in Lake Biwa in 1983. Before and during the algal bloom the number of bacteria was less than $10^{5}$ per $\mathrm{ml}$. At the end of the algal bloom, the number of bacteria rose to $10^{\beta}$ per $\mathrm{m} l$.

Fig. 6 shows the results of the growth of $U$. americana accompanied by a bacterial strain 2B-11 in the addition of heat-sterilized and nonsterilized lake water to Ur-1 medium. In all instances the growth of $U$. americana was enhanced with the

Table 1. Growth response of $U$. americana in addition of various living bacteria. Bacterial strains collected from Lake Biwa during Apr. 27 and Jun. 23, 1983 were inoculated to $U$. americana culture accompanied by a slow growing bacterium $2 \mathrm{~B}-11$

\begin{tabular}{lcccc} 
& \multicolumn{3}{c}{ No. of bacterial strains } \\
\cline { 2 - 5 } Date & Total & $\begin{array}{c}\text { Growth } \\
\text { promoted }\end{array}$ & $\begin{array}{c}\text { Growth } \\
\text { nonpromoted }\end{array}$ & $\%$ Promoted \\
\hline Apr. 27 & 24 & 24 & 0 & 100 \\
May 9 & 24 & 24 & 0 & 100 \\
May 13 & 24 & 24 & 0 & 100 \\
May 25 & 24 & 23 & 1 & 96 \\
Jun. 23 & 24 & 24 & 0 & 100 \\
\hline
\end{tabular}

- Growth of experimental cultures was compared with that of a control culture (no addition) after 14 days of incubation. Positive growth effects were considered to be those which gave more than $200 \%$ growth of the control culture (taken as $100 \%$ ). 


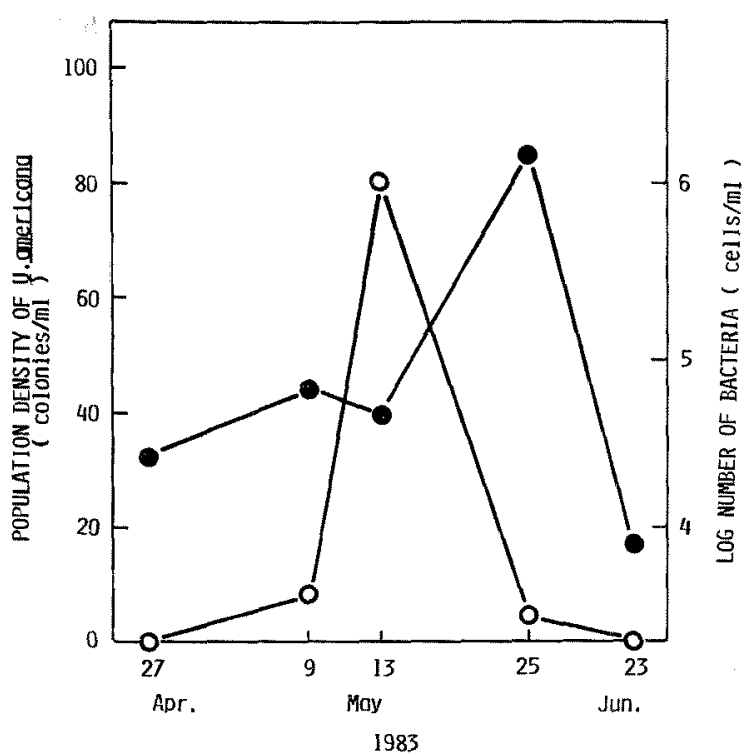

Fig. 5. Changes in the populations of $U$. americana $(O)$ and bacteria ( ) during the algal bloom in Lake Biwa, 1983.

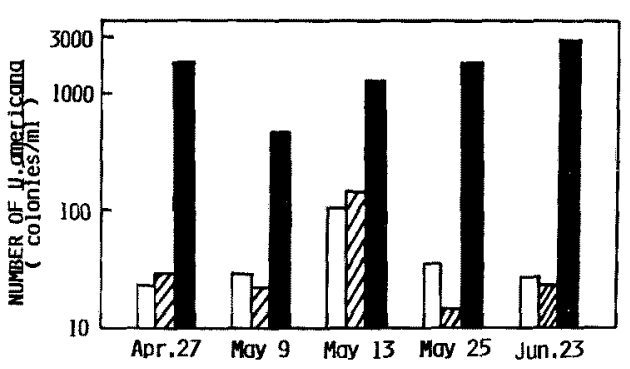

Fig, 6. Effect of natural and autoclaved lake water on the growth of U. americana. Lake water was collected from Lake Biwa on each date. A 0.1 $\mathrm{m} l$ of natural (solid bars) or autoclaved (hatched bars) lake water was added to $4 \mathrm{ml}$ of Ur-1 medium (open bars). $U$. americana culture accompanied by a bacterium 2B-11 was inoculated and incubated for 14 days.

addition of nonsterilized lake water but not with sterilized lake water. In some instances, these experiments were repeated with filter sterilization, but virtually identical results were obtained.

\section{Discussion}

The inability of $U$. americana to grow without the presence of bacteria in culture at first seemed surprising. Although numerous workers have found that algae release many substances that could be potential nutrients for bacteria, ${ }^{4-6)}$ there is little information that algal growth is dependent on the presence of bacterial associates in cultures. Lange ${ }^{7)}$ observed that under condition of carbon dioxide limitation the addition of organic carbon stimulated the growth of blue green algae via carbon dioxide production by bacteria. Berland et al ${ }^{\text {B) }}$ observed that several species grew much better in bacterized than axenic cultures and suggested release of vitamin substances by bacteria as a likely explanation of algal stimulation. Several other reports have been made as to bacterial commitment for algal growth and physiology..$^{9-12)}$

Whatever the mechanism involved, the fact that bacteria support the growth of $U$. americana in cultures suggests that there is a significant association between bacteria and $U$. americana in nature. An interesting question is: can bacteria be a limiting factor leading $U$. americana to the bloom? We have suggested that phosphorus and iron were the primary limiting nutrients in Lake Biwa by use of algal assay technique. ${ }^{12}$ Results of the present study showed that ca. $10^{5}$ per $\mathrm{m} l$ of bacteria were required to maintain exponential growth of U. americana in the laboratory (Fig. 4). Although there is some difficulty in the direct application of results in controlled laboratory experiments to a natural phenomenon, our observation that during the initial phase of the bloom 
the number of bacteria has never exceeded $10^{5}$ per $\mathrm{ml}$ in Lake Biwa (Fig. 5) suggests that the algal growth in this period might be controlled by an interaction with bacteria similar to that observed in our mixed cultures. However, it is not possible to estimate the precise role of bacteria in initiating the bloom because of the ubiquitousness of bacteria in the environment to support the algal growth (Fig. 6, Table 1). The problem, in near future, will be better elucidated by the study on the mechanism undergoing the algal-bacterial association. We will describe it in a following paper.

\section{Acknowledgements}

We thank Mr. K. Nagasaki, Kyoto University, for technical assistance. We also thank Dr. $H$. Fujisawa and Dr. M. Murakami, Shimonoseki University of Fisheries, for encouragement in preparing the manuscript. This work was supported in part by grants from the Ministry of Education of Japan (Nos. 503067, 5603007, 58560189) and the Nippon Life Insurance Fundation.

\section{References}

1) Y. Ishida, B. Kimura, H. Nakahara, and $H$. Kadota: Bull. Japan. Soc. Sci. Fish., 48, 12811287 (1982).

2) L. Provasoli and I. J. Pintner: in "The Ecology of Algae" (ed. by C. A. Tryon and R. Hartman), Spec. Publ. No. 2, University of Pittsburgh Press, Pittsburgh, 1960, pp. 84-96.

3) $Y$. Ishida, K. Shibahara, H. Uchida, and $H$. Kadota: Bull. Japan. Soc. Sci. Fish., 46, 11511158 (1980).

4) W. Bell and R. Mitchell: Biol. Bull., 143: 265277 (1972).

5) J. P. Thomas: Mar. Biol., 11, 311-323 (1971).

6) J. Bauld and T. D. Brock: J. Phycol, 10, 101106 (1974).

7) W. Lange: Can. J. Microbiol., 17, 303-314 (1971).

8) B. R. Berland, D. J. Bonnin, and S. Y. Maestrini: Mar. Biol., 5, 68-76 (1970).

9) R. Ukeles and J. Bishop: J. Phycol, 11, 142-149 (1975).

10) H. W. Paerl and P. E. Keller: J. Phycol, 14, 254-260 (1978).

11) L. Provasoli and I. J. Pintner: J. Phycol., 16, 196-201 (1980).

12) L. Machilis: J. Phycol., 9, 342-344 (1973). 